\title{
UJI EFEK ANALGESIK EKSTRAK DAUN MAHKOTA DEWA (Phaleria macrocarpa) PADA MENCIT (Mus musculus)
}

\author{
${ }^{1}$ Dinar Salsabila Tone \\ ${ }^{2}$ Jane Wuisan \\ ${ }^{2}$ Christi Mambo
}

\author{
${ }^{1}$ Kandidat Skripsi Fakultas Kedokteran Universitas Sam Ratulangi \\ ${ }^{2}$ Bagian Farmakologi dan Terapi Fakultas Kedokteran Universitas Sam Ratulangi Manado \\ Email: inay.salsa@gmail.com
}

\begin{abstract}
The plant of Mahkota Dewa is a traditional plant which is used as a medicinal plant whose benefits are located in almost parts where it contains flavonoid and saponin compounds that have a variety of effects and one of them is analgesic effect. This research aims to determine the analgesic effect of the extract of Mahkota Dewa leaf (Phaleria macrocarpa) in mices (Mus musculus). This research uses an experimental method using nine male and female mices which are divided into three groups: the positive control group that was given aspirin and the negative control that was given aquades and the treatment group that was given the extract of the Mahkota Dewa leaf. The research is done by giving the stimulus of pain in the form of heat $55^{\circ} \mathrm{C}$ and then observes the response of the tested animal such as jumping or licking its legs and at the minute of 0 before treatment, and at the minutes of 30 , 60, 90, 120 after the treatment. The average value of the number of respons of mices which were given the extract of the Mahkota Dewa leaf decreases from the 30th minute until the 90th minute. Conclusion. The extract of Mahkota Dewa leaf has an analgesic effect in Mouse. Keywords: Analgesic, Aspirin, Mahkota Dewa leaf (Phaleria macrocarpa)
\end{abstract}

\begin{abstract}
Abstrak: Tanaman mahkota dewa merupakan tumbuhan tradisional yang digunakan sebagai tumbuhan obat yang manfaatnya terletak hampir di seluruh bagian dimana di dalamnya terkandung senyawa-senyawa flavonoid dan saponin yang mempunyai bermacam-macam efek dan salah satunya adalah efek analgesik. Penelitian ini bertujuan untuk mengetahui efek analgesik dari ekstrak daun mahkota dewa (Phaleria macrocarpa) pada mencit (Mus musculus). Penelitian ini menggunakan metode eksperimental dengan menggunakan 9 ekor mencit jantan dan betina yang dibagi atas 3 kelompok yaitu kelompok kontrol positif yang diberi obat aspirin, kontrol negatif yang diberi aquades dan kelompok perlakuan yang diberi ekstrak daun mahkota dewa. Penelitian dilakukan dengan cara memberi rangsangan nyeri berupa suhu panas $55^{\circ} \mathrm{C}$ kemudian mengamati respon hewan uji berupa melompat dan atau menjilat kaki pada menit ke-0 sebelum perlakuan, dan pada menit ke-30, 60, 90, 120 setelah perlakuan. Nilai rata-rata jumlah respon mencit yang diberikan ekstrak daun mahkota dewa mengalami penurunan dari menit ke-30 sampai menit ke-90. Kesimpulan. Ekstrak daun mahkota dewa memiliki efek analgesik pada mencit.
\end{abstract}

Kata kunci: Analgesik, Aspirin, Daun Mahkota Dewa (Phaleria macrocarpa)

Sejalan dengan adanya kesadaran masyarakat untuk kembali ke alam (Back To Nature), penggunaan obat-obatan tradisional (herbal) untuk mengobati berbagai penyakit sebenarnya bukan merupakan hal yang baru lagi bagi masyarakat Indonesia. 1,2 Sejak berabadabad yang lalu, nenek moyang kita telah mewariskan secara turun temurun berbagai ramuan herbal untuk mengobati berbagai 
penyakit. Meskipun sempat tergeser dengan kemajuan ilmu pengetahuan dan teknologi modern yang semakin canggih di zaman sekarang ini terutama di bidang kesehatan, tetapi pada kenyataannya obat-obatan tradisional tak kalah ampuh untuk mengobati berbagai penyakit. Bahkan bukan tanpa alasan, obat-obatan ini cenderung lebih aman karena tidak memberikan efek samping negatif yang terlalu besar bagi tubuh. Selain itu, harganya juga cenderung lebih murah. ${ }^{1,3,4}$

Indonesia sendiri adalah rumah terbesar bagi sumber tanaman obat tradisional di dunia yang sangat kaya akan sumber khasiatnya, di dukung iklim tropis yang memungkinkan berbagai tanaman hidup subur. Di Indonesia terdiri atas 30.000 jenis tumbuhan, dimana 940 jenis di antaranya merupakan tumbuhan berkhasiat obat. ${ }^{2,3}$

Salah satu tumbuhan tradisional yang dapat digunakan sebagai tumbuhan obat yaitu daun mahkota dewa (Phaleria macrocarpa). Manfaatnya dapat di temui hampir di setiap bagian tumbuhan, meliputi batang, daun, biji, daging dan kulit buah yang didalamnya terkandung senyawasenyawa alkaloid, saponin, flavonoid, resin, tannin, polifenol, fenol, lignan, minyak asiri dan sterol. $^{5-7}$ Diantara senyawasenyawa tersebut flavonoid dan saponin mempunyai bermacam-macam efek, yaitu antitumor, anti HIV, immunostimulant, antioksidan, analgesik, antiradang (antiinflamasi), antivirus, antibakteri, antifungal, antidiare, antihepatotoksik, antihiperglikemik dan sebagai vasodilator., Berdasarkan bukti empiris, tanaman mahkota dewa berkhasiat dalam mengatasi berbagai penyakit seperti kanker, tumor, diabetes melitus, hipertensi, mengurangi rasa sakit jika terjadi pendarahan atau pembengkakan, reumatik, asam urat (arthritis gout), penyakit jantung, gangguan ginjal, eksim (penyakit kulit), jerawat dan luka gigitan serangga. ${ }^{5,10}$

Kurangnya pengetahuan dan informasi yang memadai mengenai jenis-jenis tumbuhan yang dapat dipakai sebagai ramuan obat tradisional untuk mengobati berbagai penyakit dan cara pembuatannya, yang menjadi salah satu masalah dan kesulitan bagi para peminat obat-obatan tradisional. Berdasarkan penjelasan di atas, maka penulis ingin meneliti tentang efek analgesik dari ekstrak daun mahkota dewa (Phaleria macrocarpa) terhadap mencit (Mus musculus) $^{3,4}$.

\section{METODE PENELITIAN}

Penelitian ini menggunakan metode eksperimental dan dilakukan di Laboratorium Farmakologi dan Terapi Fakultas Kedokteran Universitas Sam Ratulangi pada bulan September 2012 sampai Januari 2013. Subjek penelitian yang digunakan yaitu Mencit (Mus musculus) jantan dan betina sebanyak 9 ekor dengan berat sekitar \pm 20-40gram yang dibagi atas 3 kelompok yaitu kelompok kontrol positif yang diberi Aspirin dalam sediaan 500mg, kelompok kontrol negatif yang diberi Aquades dan kelompok perlakuan yang diberi Ekstrak daun mahkota dewa yang berwarna hijau muda dan dipetik langsung kemudian dikeringkan lalu dibuat menjadi ekstrak. Pada penelitian ini, subjek penelitian diberi rangsangan nyeri berupa suhu panas $55^{\circ} \mathrm{C}$. Kemudian diamati reaksi mengurangi rasa nyeri yang diperlihatkan oleh hewan uji berupa melompat atau menjilat kaki. Penilaian respon hewan uji diamati, kemudian dihitung berapa kali hewan melompat atau menjilat kakinya.

\section{HASIL PENELITIAN}

Data dibawah ini adalah hasil penelitian reaksi hewan uji yang berupa berapa kali mencit memberikan respon melompat dan atau menjilat kakinya saat diberikan rangsangan nyeri terhadap panas selama 1 menit dengan suhu $55^{\circ} \mathrm{C}$, sebelum pemberian zat uji, maupun pada menit ke 30, 60, 90 dan 120 setelah pemberian zat uji yang diperoleh dari pemberian perlakuan terhadap 3 kelompok mencit yang masing-masing terdiri kelompok terdiri atas 3 ekor mencit.

Kelompok pertama adalah kontrol 
positif yang diberikan obat analgesik (aspirin). Kelompok kedua adalah kelompok kontrol negatif yang diberikan aquades, dan kelompok ketiga adalah kelompok perlakuan yang diberikan ekstrak daun mahkota dewa.

Hasil penelitian pada 3 kelompok dapat dilihat pada tabel di bawah ini:

Pada Tabel 1 di atas terlihat bahwa sebelum pemberian obat, rata-rata jumlah respon mencit 62,7 kali (dibulatkan menjadi 63 kali). Pada menit ke-30 setelah pemberian obat, rata-rata jumlah respon mencit menjadi 43,7 kali (dibulatkan menjadi 44 kali), pada menit ke-60 menjadi 31,3 kali (dibulatkan menjadi 31 kali), pada menit ke-90 menjadi 32,3 kali (dibulatkan menjadi 32 kali) dan pada menit ke-120 rata-rata jumlah respon menjadi 22 kali. Berdasarkan jumlah rata-rata respon pada Tabel 1, dapat dilihat dalam bentuk grafik pada Gambar 1.

Pada Tabel 2 di atas terlihat bahwa sebelum pemberian aquades, rata-rata jumlah respon mencit 73,6 kali (dibulatkan menjadi 74 kali). Pada menit ke-30 setelah pemberian aquades, rata-rata jumlah respon mencit menjadi 52,3 kali (dibulatkan menjadi 52 kali), pada menit ke-60 menjadi 50,3 kali (dibulatkan menjadi 50 kali), pada menit ke-90 menjadi 65,3 kali (dibulatkan menjadi 65 kali) dan pada menit ke-120 menjadi 68,6 kali (dibulatkan menjadi 69 kali). Berdasarkan jumlah rata-rata respon pada Tabel 2, dapat dilihat dalam bentuk grafik pada Gambar 2 dibawah ini:

Tabel 1. Hasil pengamatan respon kelompok kontrol positif (Aspirin)

\begin{tabular}{|c|c|c|c|c|c|c|c|c|c|c|c|c|c|c|c|c|}
\hline & \multicolumn{16}{|c|}{ JUMLAH RESPON MENCIT } \\
\hline & \multirow{2}{*}{\multicolumn{3}{|c|}{$\begin{array}{c}\text { Sebelum } \\
\text { Perlakuan } \\
\text { (kali) }\end{array}$}} & \multicolumn{13}{|c|}{ Setelah Perlakuan ( Pemberian Obat ) } \\
\hline & & & & \multicolumn{3}{|c|}{ 30' } & \multicolumn{3}{|c|}{ 60' } & \multicolumn{3}{|c|}{ 90' } & \multicolumn{4}{|c|}{$120 '$} \\
\hline & $\mathrm{L}$ & $\mathrm{J}$ & $\mathbf{T}$ & $\mathrm{L}$ & $\mathrm{J}$ & $\mathbf{T}$ & $\mathrm{L}$ & $\mathrm{J}$ & $\mathbf{T}$ & $\mathrm{L}$ & $\mathrm{J}$ & $\mathbf{T}$ & $\mathrm{L}$ & $\mathrm{J}$ & $\mathbf{T}$ & \\
\hline A & - & 79 & 79 & - & 60 & 60 & - & 60 & 60 & - & 36 & 36 & - & 23 & 23 & \\
\hline $\mathbf{B}$ & - & 45 & 45 & - & 34 & 34 & - & 26 & 26 & - & 28 & 28 & - & 33 & 33 & \\
\hline C & - & 64 & 64 & - & 37 & 37 & - & 8 & 8 & - & 33 & 33 & - & 10 & 10 & \\
\hline Jumlah & & & 188 & & & 131 & & & 94 & & & 97 & & & & 66 \\
\hline Rata-rata & & & 62,7 & & & 43,7 & & & 31,3 & & & 32,3 & & & & 22 \\
\hline
\end{tabular}

Keterangan : L=Lompat $\mathbf{J}=$ Jilat $\quad \mathbf{T}=$ Total

Pembulatan bilangan desimal $=<0,5$ dan $>0,5=1$

Tabel 2. Hasil pengamatan respon kelompok kontrol negatif (Aquades)

\begin{tabular}{|c|c|c|c|c|c|c|c|c|c|c|c|c|c|c|c|}
\hline \multirow{4}{*}{ MENCIT } & \multicolumn{15}{|c|}{ JUMLAH RESPON MENCIT } \\
\hline & \multirow{2}{*}{\multicolumn{3}{|c|}{$\begin{array}{l}\text { Sebelum } \\
\text { Perlakuan } \\
\text { (kali) }\end{array}$}} & \multicolumn{12}{|c|}{ Setelah Perlakuan (kali) } \\
\hline & & & & \multicolumn{3}{|c|}{$30^{\prime}$} & \multicolumn{3}{|c|}{$60^{\prime}$} & \multicolumn{3}{|c|}{$90^{\prime}$} & \multicolumn{3}{|c|}{$120^{\prime}$} \\
\hline & $\mathrm{L}$ & $\mathrm{J}$ & $\mathbf{T}$ & $\mathrm{L}$ & $\mathrm{J}$ & $\mathbf{T}$ & $\mathrm{L}$ & $\mathrm{J}$ & $\mathbf{T}$ & $\mathrm{L}$ & $\mathrm{J}$ & $\mathbf{T}$ & $\mathrm{L}$ & $\mathrm{J}$ & $\mathbf{T}$ \\
\hline A & - & 75 & 75 & 4 & 29 & 33 & 1 & 33 & 34 & - & 72 & 72 & - & 90 & 90 \\
\hline B & - & 70 & 70 & - & 70 & 70 & - & 55 & 55 & 1 & 71 & 72 & - & 62 & 62 \\
\hline $\mathbf{C}$ & - & 76 & 76 & - & 54 & 54 & - & 62 & 62 & - & 52 & 52 & - & 54 & 54 \\
\hline Jumlah & & & 221 & & & 157 & & & 151 & & & 196 & & & 206 \\
\hline Rata-rata & & & 73,6 & & & 52,3 & & & 50,3 & & & 65,3 & & & 68,6 \\
\hline
\end{tabular}

Keterangan : L=Lompat $\mathbf{J}=$ Jilat $\quad \mathbf{T}=$ Total.

Pembulatan bilangan desimal $=<0,5$ dan $>0,5=1$ 


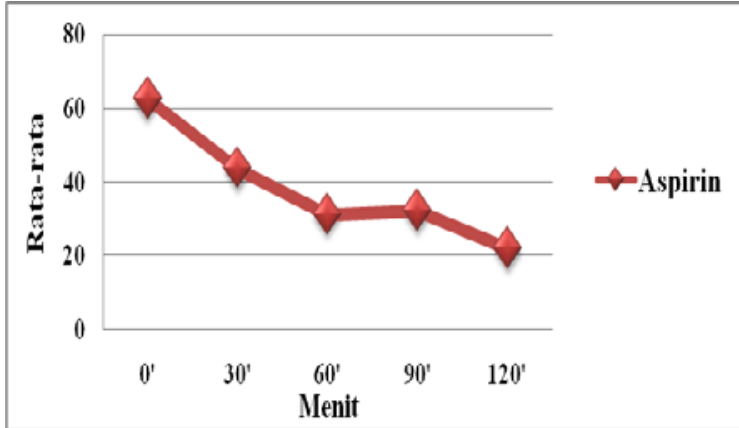

Gambar 1. Grafik rata-rata jumlah respon pada kontrol positif

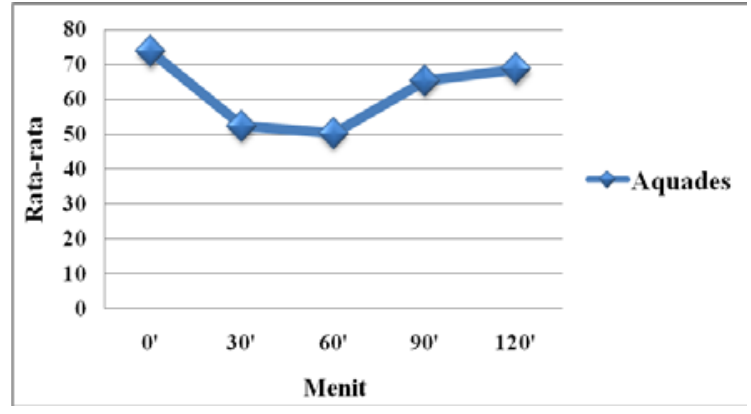

Gambar 2. Grafik rata-rata jumlah respon pada kontrol negative

Tabel 3. Hasil pengamatan respon kelompok perlakuan (ekstrak daun mahkota dewa)

\begin{tabular}{|c|c|c|c|c|c|c|c|c|c|c|c|c|c|c|c|}
\hline \multirow{4}{*}{ MENCIT } & \multicolumn{15}{|c|}{ JUMLAH RESPON MENCIT } \\
\hline & \multirow{2}{*}{\multicolumn{3}{|c|}{$\begin{array}{l}\text { Sebelum } \\
\text { Perlakuan } \\
\text { (kali) }\end{array}$}} & \multicolumn{12}{|c|}{ Setelah Perlakuan (kali) } \\
\hline & & & & \multicolumn{3}{|c|}{ 30' } & \multicolumn{3}{|c|}{ 60' } & \multicolumn{3}{|c|}{ 90' } & \multicolumn{3}{|c|}{$120^{\prime}$} \\
\hline & $\mathrm{L}$ & $\mathrm{J}$ & $\mathbf{T}$ & $\mathrm{L}$ & $\mathrm{J}$ & $\mathbf{T}$ & $\mathrm{L}$ & $\mathrm{J}$ & $\mathbf{T}$ & $\mathrm{L}$ & $\mathrm{J}$ & $\mathbf{T}$ & $\mathrm{L}$ & $\mathrm{J}$ & $\mathbf{T}$ \\
\hline $\mathbf{A}$ & 4 & 30 & 34 & 9 & - & 9 & - & 11 & 11 & 7 & 2 & 9 & 3 & 24 & 27 \\
\hline $\mathbf{B}$ & - & 56 & 56 & 0 & 64 & 64 & - & 44 & 44 & - & 16 & 16 & - & 21 & 21 \\
\hline $\mathrm{C}$ & 1 & 30 & 31 & 1 & 38 & 39 & 8 & 22 & 30 & 15 & 0 & 15 & 1 & 36 & 37 \\
\hline Jumlah & & & 121 & & & 112 & & & 85 & & & 40 & & & 85 \\
\hline Rata-rata & & & 40,3 & & & 37,3 & & & 28,3 & & & 13,3 & & & 28,3 \\
\hline
\end{tabular}

Keterangan : $\mathbf{L}=$ Lompat $\quad \mathbf{J}=$ Jilat $\quad \mathbf{T}=$ Total

Pembulatan bilangan desimal $=<0,5$ dan $>0,5=1$

Pada Tabel 3 di atas terlihat bahwa sebelum pemberian ekstrak daun mahkota dewa, rata-rata jumlah respon mencit 40,3 kali (dibulatkan menjadi 40 kali). Pada menit ke-30 setelah pemberian ekstrak, rata-rata jumlah respon mencit menjadi 37,3 kali (dibulatkan menjadi 37 kali), pada menit ke-60 menjadi 28,3 kali (dibulatkan menjadi 28 kali), pada menit ke-90 menjadi 13,3 kali (dibulatkan menjadi 13 kali) dan pada menit ke-120 menjadi 28,3 kali (dibulatkan menjadi 28 kali). Berdasarkan jumlah rata-rata respon pada Tabel 3, dapat dilihat dalam bentuk grafik pada Gambar 3 .

Pada Tabel 4 dan Gambar 4 dapat dilihat nilai rata-rata jumlah respon dari kelompok kontrol positif (aspirin), respon kelompok kontrol negatif (aquades) dan kelompok perlakuan (ekstrak daun mahkota dewa) di bawah ini:

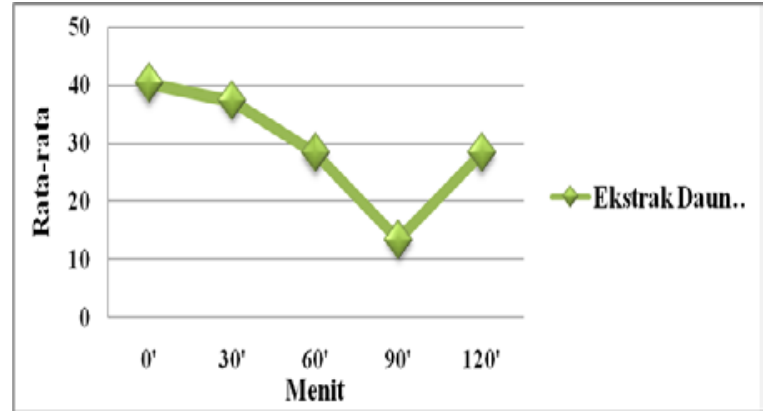

Gambar 3. Grafik rata-rata jumlah respon pada kelompok perlakuan

Tabel 4. Nilai rata-rata 3 kelompok uji

\begin{tabular}{cccccc}
\hline & $\mathbf{0}^{\prime}$ & $\mathbf{3 0}$ & $\mathbf{6 0}^{\prime}$ & $\mathbf{9 0}$ & $\mathbf{1 2 0}^{\prime}$ \\
\hline Aquades & 73.6 & 52.3 & 50.3 & 65.3 & 68.6 \\
Aspirin & 62.7 & 43.7 & 31.3 & 32.3 & 22 \\
$\begin{array}{c}\text { Ekstrak Daun } \\
\text { Mahkota } \\
\text { Dewa }\end{array}$ & 40.3 & 37.3 & 28.3 & 13.3 & 28.3 \\
\hline
\end{tabular}




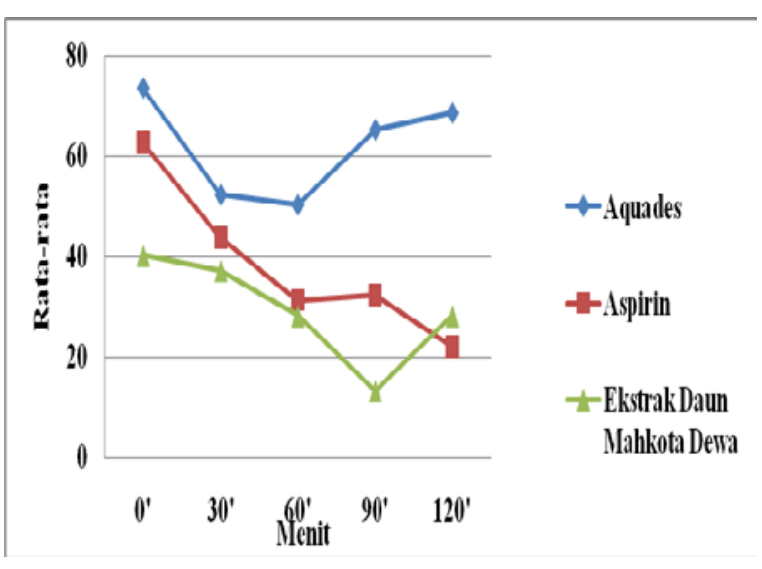

Gambar 4. Grafik perbandingan nilai rata-rata 3 kelompok uji

\section{BAHASAN}

Dalam penelitian ini telah dilakukan uji efek analgesik dari ekstrak daun mahkota dewa sebagai kelompok perlakuan, aspirin sebagai kontrol positif dan kontrol negatifnya yaitu aquades. Sebelum diberikan zat uji, terlebih dahulu dilakukan pengamatan jumlah respon hewan uji terhadap rangsangan nyeri, sehingga dapat terlihat perbandingan antara sebelum dan setelah pemberian zat uji.

Melalui pengujian hasil yang didapat pada kelompok perlakuan (ekstrak daun mahkota dewa) memperlihatkan terjadinya penurunan respon rata-rata hewan uji terhadap rangsangan nyeri yang mulai terlihat pada menit ke-30 dan mencapai maksimal pada menit ke-90. Pada menit ke120 efek analgesiknya sudah mengalami penurunan, tetapi masih memperlihatkan efek analgesiknya. Berdasarkan hasil tersebut, bahwa pemberian ekstrak daun mahkota dewa menunjukkan adanya efek analgesik pada mencit.

Pada kelompok kontrol positif yang diberikan aspirin, hasil yang didapatkan terjadi penurunan respon rata-rata hewan uji terhadap rangsangan nyeri pada menit ke-30 dari 63 kali menjadi 44 kali. Kemudian berturut-turut pada menit ke-60, 90, dan 120 menjadi 31 kali, 32 kali dan 22 kali. Efek analgesik dari kelompok kontrol positif yang diberikan aspirin mulai terlihat menurun pada menit ke-30 sampai menit ke-60 setelah pemberian zat uji, kemudian pada menit ke-90 meningkat dan pada menit ke-120 menurun lagi.

Pada kelompok kontrol negatif yang diberikan aquades, terlihat bahwa respon rata-rata hewan uji terhadap rangsangan nyeri sebelum pemberian aquades sebanyak 74 kali. Lalu pada menit ke-30 setelah pemberian aquades menurun menjadi 52 kali, pada menit ke-60 menjadi 50 kali, pada menit ke-90 dan menit ke-120 meningkat menjadi 65 kali dan 69 kali. Hal ini dikarenakan aquades hanya sebagai kontrol negatif yang tidak memberikan efek analgesik sehingga penurunan dan peningkatan respon rata-rata hewan uji tidak terlalu berpengaruh.

Hasil yang didapat dari setiap pengamatan yang dilakukan terhadap mencit yang diberikan rangsangan panas dalam beker gelas dan water bath, terlihat bahwa tidak semua mencit pada setiap kelompok menunjukkan respon yang sama terhadap rangsangan yang diberikan. Adapun respon yang diberikan hanya berupa lompatan atau hanya memberikan respon dengan menjilat kakinya dan ada juga yang menunjukkan kedua respon tersebut.

Berdasarkan hasil penelitian ini menunjukkan bahwa ekstrak daun mahkota dewa memiliki efek analgesik yang telah dilakukan pada hewan uji. Dari hasil dapat dilihat bahwa ekstrak daun mahkota dewa memiliki efek analgesik yang lebih panjang dibanding aspirin. Hal ini dapat dilihat dari efek maksimal penurunan rata-rata jumlah respon hewan uji pada ekstrak daun mahkota dewa terlihat menurun dari menit ke-30 sampai menit ke-90 dengan masa kerjanya yang lebih lama, sedangkan efek maksimal penurunan rata-rata jumlah respon hewan uji yang diberikan aspirin terlihat pada menit ke-60. Efek analgesik ekstrak daun mahkota dewa ini mungkin disebabkan oleh karena adanya peranan dari beberapa kandungan kimia yang terdapat didalamnya.

\section{SARAN}

Perlu dilakukan penelitian lebih lanjut untuk ekstrak daun mahkota dewa dengan 
menggunakan beberapa tingkatan dosis yang berbeda atau menggunakan pembanding beberapa obat analgesik lain, menggunakan metode yang berbeda dan jumlah hewan uji yang lebih banyak, serta perlu dilakukan pengujian tentang respon yang akan diberikan hewan uji berdasarkan jenis kelamin.

\section{SIMPULAN}

Dari hasil penelitian yang telah dilakukan mengenai uji efek analgesik ekstrak daun mahkota dewa (Phaleria macrocarpa) pada mencit (Mus musculus), maka dapat disimpulkan bahwa ekstrak daun mahkota dewa memiliki efek analgesik terhadap mencit.

\section{UCAPAN TERIMA KASIH}

Ditujukan kepada dr. Jane Wuisan MS, SpFK, dr. Christi Mambo, MSc, Prof. dr. Jimmy Posangi, MSc, PhD, SpFK, dr. P. M. Wowor, Mkes, SpFK dan kepada semua pihak yang baik secara langsung ataupun tidak langsung telah menumbuhkan ide atau gagasan pada penulis sehingga penulis dapat menyelesaikan artikel ini.

\section{DAFTAR PUSTAKA}

1. Mardiana L. Daun Ajaib Tumpas Penyakit. Jakarta: Penebar Swadaya, 2012; h.5-9.

2. Nugroho A. I. Lokakarya Nasional Tanaman Obat Indonesia. Dalam: koordinator nasional Asia Pasific Forest Gene- tic Resources Programme (APFORGEN) NewsLetter. Edisi 2. Jakarta: Badan penelitian dan pengembangan kehutanan; 2010.h.1. Diunduh dari: http://forplan.or.id/pdf. [28-10-2012]

3. Sari LORK. Pemanfaatan Obat Tradisional dengan Pertimbangan Manfaat dan Keamanannya.2006. Vol III.No 1.h.1-7. Available from: http://jurnal.farmasi.ui. ac.id/pdf/2006/v03n01/lusia0301.pdf [2810-2012]

4. Thomas ANS. Tanaman Obat Tradisional 2: Pendahuluan. Yogyakarta: Kanisius; 2007.h:9-10. Diunduh dari : http//books.google.co.id/books.[25-102012]

5. Dalimartha S. Atlas Tumbuhan Obat Indonesia: mahkota dewa. Jilid 3. Jakarta: Puspa Sehat, 2007; h.62-5 .

6. Apriyanti M. 10 Tanaman Obat paling berkhasiat dan paling dicari. Yogyakarta: Pustaka Baru Press, 2012; h.163-73.

7. Redaksi Better Book. Obat Murah Alami dan Berkhasiat. Jakarta: BetterBook, 2009; h.102-3.

8. Syukri Y, Saepudin. Aktivitas Penghambat Kejadian Kanker Ekstrak Etanol Buah Mahkota Dewa.2008. Vol5.No1.h.9-11. Available from: http://data.dppm.uii.ac.id/ uploads/1050102\%20Yandi\%20Saepudin. pdf [25-10-2012].

9. Soeksmanto A. Pengaruh Ekstrak Butanol Buah Tua Mahkota Dewa. Vol 7.No3.h.278-279.2006. Available from: http://biodiversitas.mipa.uns.ac.id/D/D070 3/D070317.pdf [25-10-2012]

10. Ningrum E.K, Murti M. Dahsyatnya Khasiat Herbal Untuk Hidup Sehat. Jakarta: Dunia Sehat, 2012; h.35-6. 